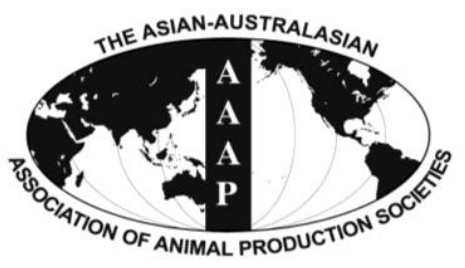

Asian-Aust. J. Anim. Sci.

Vol. 25, No. 11 : 1575-1581 November 2012

http://dx.doi.org/10.5713/ajas.2012.12251

www.ajas.info

pISSN 1011-2367 elSSN 1976-5517

\title{
Effects of Supplementing Microbially-fermented Spent Mushroom Substrates on Growth Performance and Carcass Characteristics of Hanwoo Steers (a Field Study)
}

\author{
Y. I. Kim, Y. H. Lee, K. H. Kim ${ }^{1}$, Y. K. Oh ${ }^{1}$, Y. H. Moon ${ }^{2}$ and W. S. Kwak* \\ Animal Science, School of Life Resource and Environmental Sciences, Konkuk University, \\ Danwol-Dong 322, Chung-Ju, Chung-Buk 380-701, Korea
}

\begin{abstract}
This study evaluated the effect of dietary supplementation of microbially-fermented spent mushroom substrates (MFSMS) on weight gain, carcass characteristics, and economic efficiency of Hanwoo steers. Highly cellulolytic bacteria (Enterobacter spp. and Bacillus spp.) isolated from spent mushroom substrates (SMS) stacks were inoculated (1\% v/v) into the SMS, which was anaerobically fermented and fed to the steers for 12.6 months during the growing and fattening periods. Growing Hanwoo steers were assigned to the control group without supplementation of Microbially-fermented SMS (MFSMS), to a treatment group with 50\% of MFSMS (1/2 of the ad libitum group), and to a treatment group with ad libitum access to SMS (the ad libitum group). All the groups were fed the formulated feed and rice straw. The voluntary intake (DM basis) of MFSMS was $1.6 \mathrm{~kg} / \mathrm{d}$ during the growing period and $1.4 \mathrm{~kg} / \mathrm{d}$ during the fattening period. The voluntary rice straw intake decreased by 6 to $11 \%$, but the total voluntary DMI increased by 7 to $15 \%$ with MFSMS fed. The increased DMI with MFSMS supplementation resulted in a tendency of increased $(p=0.055)$ live weight gain by 8 to $12 \%$ compared with the control group. At slaughtering, the supplementation of MFSMS increased $(\mathrm{p}<0.05)$ the ribeye area by an average of $10 \mathrm{~cm}^{2}$. In conclusion, feeding MFSMS improved growth performance and carcass traits of Hanwoo steers and could successfully replace a part of conventional roughage such as rice straw commonly used in Asian countries. (Key Words: Spent Mushroom Substrates, Spent Mushroom Compost, By-product Feed, Beef Cattle)
\end{abstract}

\section{INTRODUCTION}

Annually about 660,000 tons of spent mushroom (Pleurotus eryngii) substrates are produced in Korea. It is usually composed of sawdust, corn cob, and rice bran. Its chemical composition was $73.6 \%$ neutral detergent fiber (NDF), $55.0 \%$ acid detergent fiber (ADF), $8.1 \%$ crude protein $(\mathrm{CP}), 2.1 \%$ ether extract $(\mathrm{EE}), 9.8 \%$ non-fibrous carbohydrate (NFC), and $6.4 \%$ crude ash (Kim et al., 2007a), and based on this, the spent mushroom substrates (SMS) has potential as a feed resource for livestock.

For the effective use of SMS as animal feed, there is need to improve its preservative quality as it typically contains about $60 \%$ moisture (Kim et al., 2007a) and thus,

\footnotetext{
* Corresponding Author: Wansup Kwak. Tel: +82-43-8403521, Fax: +82-43-8518675, E-mail: wsk@kku.ac.kr

${ }^{1}$ National Institute of Animal Science, RDA, Kyungkido, Korea.

${ }^{2}$ Department of Animal Science and Biotechnology, Gyeongnam National University of Science and Technology, Gyeongnam, Korea.

Submitted May 9, 2012; Accepted Jul. 16, 2012; Revised Aug. 11, 2012
}

putrefies rapidly (Kwak et al., 2008). Ensiling the material under anaerobic conditions prevents putrefication (Kwak et al., 2008) and improves the preservative quality (Kim et al., 2007b; Kim et al., 2008b). In previous studies Kim et al. (2007b; 2008a; 2008b) have identified the presence of highly cellulolytic bacteria in the SMS. Furthermore, it was found that SMS exhibited good preservative quality for eight weeks after inoculation with the identified bacteria and fermenting agents. The change in the nutritional constituents was found to be slight, and after eight weeks of anaerobic storage, the number of microorganisms such as yeast and lactobacillus remained high at $10^{8} \mathrm{cfu} / \mathrm{g}$. These results suggested that the microbes inoculated into SMS could be used also as direct-fed microbes (DFM) for livestock.

In the aspect of DFM, Krebiel et al. (2003) clearly described the benefit of supplementation with DFM such as improved weight gain and feed efficiency in ruminants. Currently available commercial DFM are expensive, making them impractical to feed to livestock. It was 
hypothesized that if low-priced DFM produced from SMS were fed to Hanwoo steers, their effect could be maximized In addition, such low-priced DFM culture could partly replace conventional roughage (rice straw) because of the high amount of cellulose contained in SMS. As fresh SMS is mostly used as an ingredient of total mixed rations (TMR), more diverse usages need to be explored. At present, there have been no attempts to use Microbially-fermented SMS (MFSMS) as a component of the ration for growing and fattening beef steers.

In this context, a field study was performed to evaluate the effect of dietary supplementation of MFSMS on the weight gain, carcass characteristics, and economic efficiency of growing and fattening Hanwoo steers.

\section{MATERIALS AND METHODS}

\section{Microbial fermentation of SMS}

The spent substrates used to grow mushrooms (Pleurotus eryngii) were used as the test feed. The original substrates used to grow mushrooms consisted of $49 \%$ sawdust, $32 \%$ rice bran, and $19 \%$ corn cob. Fresh, spent substrates from a commercial mushroom farm located at the suburb of Chung-ju City, Korea were obtained on the day of mushroom harvest and transferred to the Konkuk University Experimental Station. The SMS were screened using a 20 $\mathrm{mm} \times 20 \mathrm{~mm}$ (width $\times$ length) sieve to remove lumps and foreign materials. Four strains of bacteria (Enterobacter ludwigii, Bacillus cereus, and two strains of Bacillus subtilis) were cultured for $12 \mathrm{~h}$ in plate count broth, and then inoculated $(1 \% \mathrm{v} / \mathrm{v})$ into the SMS. These bacterial species had been previously isolated and identified from the SMS and were found to have high CMCase and xylanase activities (Kim et al., 2007b; 2008b). The inoculated SMS was packed into plastic bags inside an empty feed sack and sealed to prevent air from getting in. The material was left to undergo fermentation for more than two weeks at the ambient temperature, and then the fermented SMS (total bacteria count, $10^{8}$ to $10^{9} \mathrm{cfu} / \mathrm{g}$ ) was fed to Hanwoo steers.

\section{Animals and treatment}

Eighteen Hanwoo steers (nine months old and $227 \pm 20$ $\mathrm{kg}$ ) were selected and randomly assigned to a control group (without SMS supplementation), a treatment group with $50 \%$ of SMS (the $1 / 2$ of ad libitum group), and a treatment group with ad libitum access to SMS (the ad libitum group).

All of the groups were fed the same amount of formulated feed. The growing period was from nine to 13 months of age, during which the steers were fed the formulated feed at an average amount of $1.75 \%$ (as-fed basis) of the body weight. The fattening period was from 14 to 22 months of age, during which the steers were fed the formulated feed at an average amount of $1.85 \%$ of the body weight. The finishing period was from 24 to 30 months of age, during which the steers were restricted-fed the formulated feed at $9 \mathrm{~kg} / \mathrm{d}$. The formulated feed was restricted-fed during the growing and fattening period in order to prevent excessive gain and during the finishing period in order to prevent excessive back fat thickness.

During the growing and fattening periods, steers had free access to rice straw; however, during the finishing period, the steers were restricted to $1.0 \mathrm{~kg} / \mathrm{d}$ (as-fed basis) of rice straw. The SMS was fed only during the growing and fattening periods by top-dressing it on the formulated feed. The SMS were not fed during the finishing period in order to meet the maximum energy requirement with high energy-containing formulated feed, which is normal feeding practice in this period. Steers had free access to fresh water during the entire feeding trial. The chemical composition of the formulated feed, rice straw and SMS is shown in Table 1. The CP and EE contents were slightly higher in SMS than in rice straw. The crude ash content of SMS was $6 \%$, equating to about half that of the rice straw. The NDF content of SMS was similar to that of rice straw. Physically, the mean particle size of SMS was $4 \mathrm{~mm}$, being much smaller than that of the rice straw.

\section{Sampling and analysis}

Representative samples of the test feeds and the formulated feed that were fed to the Hanwoo steers were

Table 1. Chemical composition of feeds fed to Hanwoo steers ${ }^{1}$

\begin{tabular}{|c|c|c|c|c|c|}
\hline \multirow{2}{*}{ Item } & \multicolumn{3}{|c|}{ Formulated feed } & \multirow{2}{*}{ Rice straw } & \multirow{2}{*}{ MFSMS $^{2}$} \\
\hline & Growing & Fattening & Finishing & & \\
\hline Dry matter & 87.2 & 88.1 & 90.1 & 85.5 & 41.2 \\
\hline Crude protein & 14.9 & 15.5 & 12.4 & 4.2 & 5.7 \\
\hline Ether extract & 3.8 & 4.2 & 3.3 & 0.4 & 1.4 \\
\hline Crude ash & 8.4 & 8.3 & 6.7 & 12.1 & 6.0 \\
\hline Neutral detergent fiber & 37.6 & 33.8 & 25.2 & 75.7 & 78.8 \\
\hline Acid detergent fiber & 20.9 & 20.2 & 13.3 & 44.2 & 66.0 \\
\hline Hemicellulose & 16.7 & 13.6 & 11.9 & 31.5 & 12.8 \\
\hline Non-fibrous carbohydrate & 35.3 & 38.2 & 52.4 & 7.6 & 8.1 \\
\hline
\end{tabular}

${ }^{1}$ On dry matter basis. ${ }^{2}$ MFSMS = Microbially-fermented spent mushroom substrates. 
collected and stored in a freezer at $-20^{\circ} \mathrm{C}$ (Lassele LOC$520 \mathrm{~F}$, Korea) until the analysis. The samples were thawed in the refrigerator prior to analysis. Dry matter (DM), CP, EE, crude fiber (CF), NDF, acid detergent fiber (ADF) and crude ash were analyzed according to the AOAC method (2000). Non-fibrous carbohydrate was calculated using the formula $100-(\mathrm{NDF}+\mathrm{CP}+\mathrm{EE}+$ crude ash).

The body weight (BW) of the steers was measured monthly. The back fat thickness and the marbling degree were measured at 24 months of age using an ultrasound (Aloka SSD-500, USA). Steers were slaughtered at 31 months of age. Following a 48-h carcass chill, yield and quality grade of each carcass were measured using Korean carcass grading standards specified in Korean Livestock Enforcement Regulation (KMAF, 2007).

\section{Statistical analysis}

The General Linear Model was used for the statistical analysis (Statistix 7, 2000). To compare the mean values, orthogonal contrast was performed as follows: the control vs the 1/2 of ad libitum group and the ad libitum group; and the $1 / 2$ of ad libitum group vs the ad libitum group.

\section{RESULTS AND DISCUSSION}

\section{Feed intake and weight gain of the Hanwoo steers}

The feed intake of the growing Hanwoo steers with SMS supplementation is shown in Table 2. Under the formulated feed and rice straw feeding system, when SMS was top-dressed on formulated feed, the daily voluntary intake of SMS was $1.6 \mathrm{~kg}$ in the growing period and $1.4 \mathrm{~kg}$

Table 2. Effect of dietary supplementation of microbiallyfermented spent mushroom substrates (MFSMS) on feed intake of Hanwoo steers ${ }^{1}$

\begin{tabular}{lccc}
\hline & & \multicolumn{2}{c}{ Feeding MFSMS } \\
\cline { 3 - 4 } Item & Control & $\begin{array}{c}1 / 2 \text { of } \\
\text { ad libitum }\end{array}$ & Ad libitum \\
\hline Growing period $(\mathrm{kg} / \mathrm{d})$ & & & \\
Formulated feed & 4.53 & 4.53 & 4.53 \\
Rice straw & 2.91 & 2.74 & 2.57 \\
MFSMS & - & 0.82 & 1.64 \\
Total DM intake & 7.44 & 8.09 & 8.74 \\
Total CP intake & 0.80 & 0.84 & 0.88 \\
Fattening period (kg/d) & & & \\
Formulated feed & 7.31 & 7.31 & 7.31 \\
Rice straw & 2.31 & 2.14 & 1.97 \\
MFSMS & - & 0.71 & 1.42 \\
Total DM intake & 7.44 & 8.09 & 8.74 \\
Total CP intake & 1.23 & 1.26 & 1.30 \\
Finishing period (kg/d) & & & \\
Formulated feed & 8.29 & 8.29 & 8.29 \\
Rice straw & 0.86 & 0.86 & 0.86 \\
Total DM intake & 9.14 & 9.14 & 9.14 \\
\hline Dry & & &
\end{tabular}

in the fattening period, which was equivalent to about 11 to $16 \%$ of the total DM intake (DMI)

When SMS was supplemented, the total DMI increased by 7 to $15 \%$; however, rice straw intake decreased by 6 to $11 \%$ during the growing period. The Hanwoo steers showed relatively high preference for the MFSMS. The increase in total DMI was a reflection of the high SMS intake because feeding the formulated feed was equally restricted to all experimental steers during the growing period. Also, it is believed that because of the decreased intake of rice straw with long particle size and the increased intake of SMS with a relatively small particle size of $4 \mathrm{~mm}$, the mean particle size of the ingested feed decreased, which probably resulted in increased DMI. Jaster and Murphy (1983) and Kato et al. (1989) reported that when steers were fed with a feed with a small particle size, total DMI increased. As the NDF content of SMS (78.8\%) was $3.1 \%$ higher than that of the rice straw, the total NDF intake by the treatment groups was $5.5 \mathrm{~kg} / \mathrm{d}$, which reflects a $22.3 \%$ increase from $4.5 \mathrm{~kg} / \mathrm{d}$ in the control group. Generally, if NDF intake increases, DMI decreases (Forbes, 1995; Lee et al., 2002). In the present study; however, both NDF intake and DMI increased with SMS supplementation. Although the mean particle size of SMS was $4 \mathrm{~mm}$, larger than the $1.18 \mathrm{~mm}$ that Sniffen et al. (1992) suggested as the minimum particle size that is capable of inducing rumination, it was much smaller than that of the rice straw. It can thus be postulated that the increased DMI was due to the faster movement of the SMS to the lower intestine due to their small particle size. Supplementing with SMS increased total CP intake by 5 to $10 \%$ during the growing period and by 3 to $6 \%$ during the fattening period.

The effect of SMS supplementation on the growth performance of Hanwoo steers is shown in Table 3. During the growing period, supplementing SMS did not affect weight gain $(p>0.05)$. During the fattening period, the $1 / 2$ of ad libitum group gained more than the ad libitum group $(\mathrm{p}<0.05)$. During the finishing period, all the SMS-fed groups tended $(\mathrm{p}=0.061)$ to have approximately 24 to 40 $\mathrm{kg}$ more weight gain compared to the control group. As a result, the $\mathrm{BW}$ of the animals over the whole period was 8 to $12 \%$ (approximately 36 to $52 \mathrm{~kg} / \mathrm{head}$ ) more in the SMSsupplemented groups than in the control group. These results were attributed to the increased DM and CP intakes and possibly to the favorable effect of the microbes fed. Huck et al. (2000) reported that the weight gain of feedlot cattle with added direct-fed microbes (DFM) increased by 2.5 to $3.0 \%$. Galyean et al. (2000) also reported that dietary addition of DFM increased the body weight of feedlot cattle. It is believed that feeding MFSMS favorably affected the growth of Hanwoo steers because it functions as sources of roughage as well as DFM. 
Table 3. Effect of dietary supplementation of microbially-fermented spent mushroom substrates (MFSMS) on growth performance of Hanwoo steers ${ }^{1}$

\begin{tabular}{|c|c|c|c|c|c|c|}
\hline \multirow[b]{2}{*}{ Item } & \multirow{2}{*}{$\begin{array}{l}\text { Control } \\
\text { (A) }\end{array}$} & \multicolumn{2}{|c|}{ Feeding MFSMS } & \multirow[b]{2}{*}{ SE } & \multicolumn{2}{|c|}{ Significance of contrast } \\
\hline & & $\begin{array}{l}1 / 2 \text { of ad libitum } \\
\text { (B) }\end{array}$ & $\begin{array}{l}\text { Ad libitum } \\
\text { (C) }\end{array}$ & & $\begin{array}{l}\text { Avs. } \\
B+C\end{array}$ & $\begin{array}{c}\text { B vs. } \\
\text { C }\end{array}$ \\
\hline & & 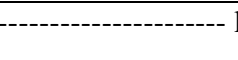 & 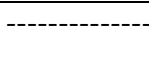 & 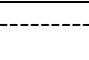 & & \\
\hline \multicolumn{7}{|l|}{ Growing period } \\
\hline Initial BW (9.6 mo old) & 227.0 & 226.8 & 228.3 & 12.3 & 0.9600 & 0.8991 \\
\hline Final BW (14.6 mo old) & 356.3 & 361.0 & 354.3 & 13.8 & 0.9102 & 0.6329 \\
\hline Gain & 129.3 & 134.3 & 125.9 & 7.6 & 0.9005 & 0.2880 \\
\hline $\mathrm{ADG}$ & 0.84 & 0.88 & 0.82 & 0.05 & 0.9010 & 0.2907 \\
\hline \multicolumn{7}{|l|}{ Fattening period } \\
\hline Initial BW (14.6 mo old) & 356.3 & 361.0 & 354.3 & 13.8 & 0.9102 & 0.6329 \\
\hline Final BW (22.2 mo old) & 555.8 & 584.5 & 553.3 & 21.4 & 0.4918 & 0.1666 \\
\hline Gain $^{\mathrm{a}}$ & 203.3 & 223.5 & 199.1 & 9.8 & 0.3612 & 0.0252 \\
\hline $\mathrm{ADG}$ & 0.88 & 0.97 & 0.86 & 0.04 & 0.3595 & 0.0755 \\
\hline \multicolumn{7}{|l|}{ Finishing period } \\
\hline Initial BW (22.2 mo old) & 555.8 & 584.5 & 553.3 & 21.4 & 0.4918 & 0.1666 \\
\hline Final BW (31.0 mo old) & 659.8 & 712.2 & 697.5 & 26.4 & 0.0656 & 0.5820 \\
\hline Gain & 104.0 & 127.7 & 144.2 & 18.1 & 0.0610 & 0.3779 \\
\hline $\mathrm{ADG}$ & 0.41 & 0.46 & 0.53 & 0.06 & 0.1437 & 0.3287 \\
\hline \multicolumn{7}{|l|}{ Whole period } \\
\hline Initial BW (9.6 mo old) & 227.0 & 226.8 & 228.3 & 12.3 & 0.9600 & 0.8991 \\
\hline Final BW (31.0 mo old) & 659.8 & 712.2 & 697.5 & 26.4 & 0.0656 & 0.5820 \\
\hline Gain & 433.4 & 485.4 & 469.2 & 24.2 & 0.0551 & 0.5132 \\
\hline $\mathrm{ADG}$ & 0.68 & 0.73 & 0.71 & 0.04 & 0.2030 & 0.5902 \\
\hline
\end{tabular}

${ }^{1}$ Least square means of 6 observations.

a $1 / 2$ of ad libitum group differs from ad libitum group.

\section{Carcass characteristics}

An ultrasound scanning test was conducted when the Hanwoo steers were 24 months of age. The back fat thickness and marbling score are shown in Table 4. Supplementing SMS did not affect the back fat thickness ( $p>0.05)$ with the fat thickness of all steers being in the range of 7.1 to $9.8 \mathrm{~mm}$. Kim et al. (2003) reported a similar level $(9.3 \pm 0.4 \mathrm{~mm})$ at 24 months of age. Supplementing MFSMS did not affect marbling score at 24 months of age $(\mathrm{p}>0.05)$.

All the experimental steers were slaughtered at 31 months of age; the carcass characteristics are shown in Table 5. Supplementing SMS did not affect the cold carcass weight, yield index and yield grade ( $p>0.05)$. However, the ribeye area increased $(\mathrm{p}<0.05)$ by 9.5 to $10.3 \mathrm{~cm}^{2}$ by supplementing MFSMS. The growth of ribeye area has been known to be affected by age, body weight and feed. The active growth of Hanwoo ribeye area reaches a peak at around 11 months of age and its growth continues until 18 months of age (HFMC, 2009). Okumura et al. (2007) reported that the ribeye area of Japanese Black steers (twins) was not different between 24 and 30 months of age. Thus, muscle growth seems complete before maturity. The feeding management during the growing and early fattening period seems to be important to maximize ribeye area. Ribeye area has been found to be correlated positively with weight gain (Kang et al., 1995), slaughter weight up to 24 months of age of Hanwoo steers (Moon et al., 2003) and cold carcass weight of Hanwoo steers (Park et al., 2002) and goats (Palmieri et al., 2012). Dietary protein levels may or may not affect ribeye area depending upon experimental conditions. Feeding high levels of protein in the early

Table 4. Effect of dietary supplementation of microbially-fermented spent mushroom substrates (MFSMS) on back fat thickness and marbling score of Hanwoo steers measured by ultrasound scanning ${ }^{1,2}$

\begin{tabular}{|c|c|c|c|c|c|c|}
\hline \multirow[b]{2}{*}{ Item } & \multirow[b]{2}{*}{$\begin{array}{l}\text { Control } \\
\text { (A) }\end{array}$} & \multicolumn{2}{|c|}{ Feeding MFSMS } & \multirow[b]{2}{*}{ SE } & \multicolumn{2}{|c|}{ Significance of contrast } \\
\hline & & $\begin{array}{l}1 / 2 \text { of ad libitum } \\
\text { (B) }\end{array}$ & $\begin{array}{l}\text { Ad libitum } \\
\text { (C) }\end{array}$ & & $\mathrm{A}$ vs $\mathrm{B}+\mathrm{C}$ & $\mathrm{B}$ vs $\mathrm{C}$ \\
\hline Back fat thickness (mm) & 9.8 & 9.5 & 7.1 & 1.6 & 0.3040 & 0.1420 \\
\hline Marbling score & 2.4 & 2.2 & 2.3 & 0.5 & 0.7188 & 0.7550 \\
\hline
\end{tabular}

${ }^{1}$ Means of 6 observations. ${ }^{2}$ Ultrasound scanning was measured at 24 months of age. 
Table 5. Carcass characteristics of Hanwoo steers supplemented with microbially-fermented spent mushroom substrates (MFSMS) ${ }^{1}$

\begin{tabular}{|c|c|c|c|c|c|c|}
\hline \multirow[b]{2}{*}{ Item } & \multirow{2}{*}{$\begin{array}{l}\text { Control } \\
\text { (A) }\end{array}$} & \multicolumn{2}{|c|}{ Feeding MFSMS } & \multirow[b]{2}{*}{ SE } & \multicolumn{2}{|c|}{ Significance of contrast } \\
\hline & & $\begin{array}{l}1 / 2 \text { of ad libitum } \\
\text { (B) }\end{array}$ & $\begin{array}{l}\text { Ad libitum } \\
\text { (C) }\end{array}$ & & $A$ vs $B+C$ & B vs $\mathrm{C}$ \\
\hline Marketing weight (kg) & 659.8 & 712.2 & 697.5 & 26.4 & 0.0656 & 0.5820 \\
\hline Cold carcass weight $(\mathrm{kg})$ & 396.6 & 414.5 & 400.7 & 16.9 & 0.4649 & 0.4263 \\
\hline \multicolumn{7}{|l|}{ Yield traits ${ }^{2}$} \\
\hline Back fat thickness (mm) & 17.4 & 17.3 & 11.5 & 4.0 & 0.4002 & 0.1639 \\
\hline Ribeye area $\left(\mathrm{cm}^{2}\right)^{\mathrm{a}}$ & 77.4 & 86.8 & 87.7 & 4.1 & 0.0150 & 0.8420 \\
\hline Yield index & 61.1 & 61.9 & 66.0 & 2.8 & 0.2568 & 0.1712 \\
\hline Yield grade (A:B:C) & $1: 2: 2$ & $0: 4: 2$ & $1: 4: 1$ & - & - & - \\
\hline \multicolumn{7}{|l|}{ Quality traits ${ }^{3}$} \\
\hline Marbling score & 5.2 & 4.5 & 5.7 & 0.8 & 0.8656 & 0.1575 \\
\hline Meat color & 4.6 & 5.0 & 5.0 & 0.2 & 0.0502 & - \\
\hline Fat color & 3.0 & 2.8 & 3.0 & 0.1 & 0.5057 & 0.2564 \\
\hline Texture & 1.6 & 2.0 & 2.0 & 0.3 & 0.0761 & - \\
\hline Maturity & 2.0 & 2.0 & 2.0 & - & - & - \\
\hline
\end{tabular}

fattening stage did not affect ribeye area of Japanese Black heifers (Okumura et al., 2008). Feeding 12 to $18 \%$ dietary $\mathrm{CP}$ from 10 to 20 months old did not affect ribeye area of Japanese Black steers (Iwamoto et al., 2010). Although feeding 11.5 to $14.5 \%$ dietary CP levels did not affect ribeye area, CP source (urea or cottonseed meal) affected ribeye area of finishing beef steers (Gleghorn et al., 2004). However, feeding more concentrate feed with high CP during the growing period has been shown to increase ribeye area of British breed beef steers (Sainz et al., 1995). In the present study, the SMS-fed steers had a higher dietary $\mathrm{CP}$ intake, heavier weight and greater ribeye area $(\mathrm{p}<0.05)$. The increased ribeye area of SMS-fed steers was attributed to the increased $\mathrm{CP}$ intake under the low dietary $\mathrm{CP}(10.4 \%)$ and restricted concentrates feeding situation in the growing and early fattening stage of Hanwoo steers.

The back fat thickness of the ad libitum group steers was $6 \mathrm{~mm}$ less than the $1 / 2$ of ad libitum group steers, although the difference was not significant $(\mathrm{p}>0.05)$ due to the large variations between animals. When compared with the ultrasound results (Table 4), the increase in the back fat thickness at 31 months of age (seven months after the body weight measurement using the ultrasound test) differed considerably between individuals. The mean increase in the back fat thickness was $6.66 \mathrm{~mm}$. During the same period, the marbling score increased by an average of 2.9 grades although the difference was not significant among treatments.

Meat color, fat color, texture and maturity were not affected by supplementing SMS ( $>>0.05)$. These scores of both the control and the treatment groups were in the normal range. Ware et al. (1988) also reported that although supplementation with DFM increased the BW of steers, it did not have any influence on the marbling score.

\section{Economic efficiency}

The effect of supplementation with SMS on the economic efficiency of Hanwoo steers is shown in Table 6. The mean gross income from selling a Hanwoo steer in the treatment groups was 4.1 to $4.8 \%$ higher than that in the control group. The feed cost per $1 \mathrm{~kg}$ weight gain of Hanwoo steers was $13.9 \%$ lower for the $1 / 2$ ad libitum group and $9.6 \%$ lower for the ad libitum group than that for the control group $(\mathrm{p}<0.05)$. The mean net income per Hanwoo steer in the treament groups was 84 to $65 \%$ higher than that of the control group. These results were attributed to both the feed cost savings and the increased BW by SMS supplementation.

\section{IMPLICATION}

Microbial fermentation seemed to improve palatability and stable storage of fresh SMS. The MFSMS would be able to effectively replace not only a part of conventional low-quality roughage such as rice straw but also microbial additives for beef cattle. Either restricted or ad libitum feeding of SMS showed similar growth performance and carcass traits in Hanwoo steers. The MFSMS may be used as a cheap ingredient of TMR for ruminants. The MFSMS can be successfully recycled as an animal feed in mushroom-cultivating and feed-lacking Asian countries. 
Table 6. Effect of dietary supplementation of microbially-fermented spent mushroom substrates (FMSMS) on economic profit of Hanwo steers ${ }^{1}$

\begin{tabular}{|c|c|c|c|c|c|c|}
\hline \multirow[b]{2}{*}{ Item } & \multirow{2}{*}{$\begin{array}{l}\text { Control } \\
\text { (A) }\end{array}$} & \multicolumn{2}{|c|}{ Feeding MFSMS } & \multirow[b]{2}{*}{ SE } & \multicolumn{2}{|c|}{ Significance of contrast } \\
\hline & & $\begin{array}{c}1 / 2 \text { of ad libitum } \\
\text { (B) }\end{array}$ & $\begin{array}{l}\text { Ad libitum } \\
\text { (C) }\end{array}$ & & $A$ vs $B+C$ & $\mathrm{~B}$ vs $\mathrm{C}$ \\
\hline & ------------- & ---- 1,000 won --- & -------------- & & & \\
\hline Gross receipts $^{2}$ & 5,621 & 5,893 & 5,850 & 205 & 0.3356 & 0.8846 \\
\hline Operating cost & 5,159 & 5,043 & 5,089 & - & & - \\
\hline Calf $^{3}$ & 2,319 & 2,319 & 2,319 & - & & - \\
\hline Feed & 2,840 & 2,724 & 2,770 & - & & - \\
\hline Net income ${ }^{4}$ & 462 & 850 & 761 & 205 & 0.1938 & 0.7626 \\
\hline Feed cost/gain $(\mathrm{kg})^{\mathrm{a}}$ & 6.57 & 5.66 & 5.94 & 0.31 & 0.0124 & 0.3807 \\
\hline
\end{tabular}

${ }^{1}$ On the basis of concentrate 450 won $/ \mathrm{kg}$, rice straw $290 \mathrm{won} / \mathrm{kg}$, and microbially-fermented spent mushroom substrates $80 \mathrm{won} / \mathrm{kg}$.

${ }^{2}$ Selling price of carcass by grade and by-product. ${ }^{3}$ Average purchased price of calf in the livestock market.

${ }^{4}$ Net income $=$ Gross receipts-operating cost.

${ }^{\text {a }}$ Control group differs from $1 / 2$ of ad libitum and ad libitum groups.

\section{ACKNOWLEDGEMENTS}

This study was conducted by means of a grant from the Agenda Research Program (PJ007474092011) of the Rural Development Administration, Korea.

\section{REFERENCES}

AOAC. 2000. Official methods of analysis, 17th Ed. Association of Official Analytical Chemists, Washington, DC, USA.

Forbes, J. M. 1995. Voluntary food intake and diet selection in farm animal. CAB International. Wallingford, Oxon, UK.

Galyean, M. L., G. A. Nunnery, P. J. Defoor, G. B. Salyer and C. H. Parsons. 2000. Effects of live cultures of Lactobacillus acidophilus (strains 45 and 51) and Propionibacterium freudenreichii PF-24 on performance and carcass characteristics of finishing beef steers. Burnett Center Internet Progress Report No:8, USA.

Gleghorn, J. F., N. A. Elam, M. L. Galyean, G. C. Duff, N. A. Cole and J. D. Rivera. 2004. Effects of crude protein concentration and degradability on performance, carcass characteristics, and serum urea nitrogen concentrations in finishing beef steers. J. Anim. Sci. 82:2705-2717.

Hanwoo Fund Management Commettee. 2009. Hanwoo Counsulting Manual. Korean Society of Animal Science, Hanwoo Research Agency, Korea.

Huck, G. L., K. K. Kreikemeier and G. A. Ducharme. 2000. Effects of feeding two microbial additives in sequence on growth performance and carcass characteristics of finishing heifers. Kansas State University Cattlemen's Day 2000, Report of Progress, KSU Agric. Exp. St. and Coop. Ext. Service. pp. 3234, USA.

Ivamoto, E., F. Iwaki and A. Oka. 2010. Effects of dietary protein level in the early fattening period on free amino acids and dipeptides in the blood and longissimus thoracis muscle in Japanese Black steers. Anim. Sci. J. 81:338-344.

Jaster, E. H. and M. R. Murphy. 1983. Effects of varying particle size of forage on digestion and chewing behavior of dairy heifers. J. Dairy Sci. 66:802-810.
Kang, S. W., Y. H. Chung, Y. S. Son and Y. K. Kim. 1995. Effects of growing-fattening period on the growth patterns of bone, muscle and fat in the carcass of Korean native bulls. Korean J. Anim. Nutr. Feed. 19:242-252.

Kato, K., Y. Kajima, M. Odashima, L. S. Lee, K. T. Nam, H. Chiga, Y. Shoji, M. Otha and Y. Sasaki. 1989. Feed passage and digestibility in Japanese deer and sheep. Research Report of Kawatabi Experimental Station. 5:59-62.

Kim, H. C., D. H. Lee, S. B. Choi and G. J. Jeon. 2003. Relationship between ultrasonic and carcass measures for meat qualities in Hanwoo steers. J. Anim. Sci. Technol. (Kor.). 45:183-190.

Kim, Y. I., J. S. Bae, S. H. Jung, M. H. Ahn and W. S. Kwak. 2007a. Yield and physicochemical characteristics of spent mushroom (Pleurotus ryngii, Pleurotus osteratus and Ammulina velutipes) substrates according to mushroom species and cultivation types. J. Anim. Sci. Technol. (Kor.) 49:79-88.

Kim, Y. I., J. S. Seok and W. S. Kwak. 2008a. Effect of mixed microbes addition on chemical change and silage storage of spent mushroom substrates. J. Anim. Sci. Technol. (Kor.) 50:831-848.

Kim, Y. I., S. H. Jung, J. S. Seok, S. Y. Yang, J. W. Huh and W. S. Kwak. 2007b. Isolation and identification of high cellulolytic bacteria from spent mushroom substrate and determination of optimal medium conditions for the growth. Kor. J. Microbiol. Biotechnol. 35:255-260.

Kim, Y. I., S. H. Jung, J. S. Seok, S. Y. Yang, J. W. Huh and W. S. Kwak. 2008b. Isolation and identification of hydrolytic enzyme-producing bacteria from spent mushroom substrate. J. Anim. Sci. Technol. (Kor.) 50:713-720.

Korean Ministry of Agriculture and Forest. 2007. Carcass grading standards. Livestock Regulation Practice, Appendix no. 4, KMAF, Korea.

Krehbiel, C. R., S. R. Rust, G. Zhang and S. E. Gilliland. 2003. Bacterial direct-fed microbials in ruminant diets: Performance response and mode of action. American Society of Animal Science, J. Anim. Sci. 81(E.Suppl. 2):E120-E132.

Kwak, W. S., S. H. Jung and Y. I. Kim. 2008. Broiler litter supplementation improves storage and feed-nutritional value 
of sawdust-based spent mushroom substrate. Bioresour. Technol. 99:2947-2955.

Lee, S. C., Y. W. Moon, H. J. Lee, Y. G. Oh and K. H. Kim. 2002. Prediction of dry matter intake of Hanwoo bulls. J. Anim. Sci. Technol. (Kor.) 43:341-350.

Moon, S. S., I. H. Hwang, S. K. Jin, J. G. Lee, S. T. Joo and G. B. Park. 2003. Carcass traits determining quality and yield grades of Hanwoo steers. Asian-Aust. J. Anim. Sci. 16:1049-1054.

Okumura, T., K. Saito, H. Sakuma, T. Nade, S. Nakayama, K. Fujita and T. Kawamura. 2007. Intramuscular fat deposition in principal muscles from twenty-four to thirty months of age using identical twins of Japanese Black steers. J. Anim. Sci. 85:1902-1907.

Okumura, T., K. Saito, T. Nade, S. Misumi, H. Sakuma, S Nakayama, Y. Masuda, K. Fujita and T. Kawamura. 2008. Effects of high protein levels in concentrate feed during the early fattening stage on physic-chemical composition and sensory characteristics of M. longissimus in Japanese Black heifers. Anim. Sci. J. 79:332-338
Palmieri, A. D., R. L. Oliveira, C. V. D. M. Ribeiro, M. D. Ribeiro, R. D. X. Ribeiro, A. G. Leao, M. S. F. A. Agy and O. L. Ribeiro. 2012. Effects of substituting soybean meal for sunflower cake in the diet on the growth and carcass traits of crossbred Boer goat kids. Asian-Aust. J. Anim. Sci. 25:59-65.

Park, G. B., S. S. Moon, Y. D. Ko, J. K. Ha, J. G. Lee, H. H. Chang and S. T. Joo. 2002. Influence of slaughter weight and sex on yield and quality grades of Hanwoo (Korean native cattle) carcasses. J. Anim. Sci. 80:129-136.

Sainz R. D., F. De la Torre and J. W. Oltjen. 1995. Compensatory growth and carcass quality in growth-restricted and refed beef steers. J. Anim. Sci. 73:2971-2979.

Sniffen, C. J., J. D. O'Connor, P. J. Van Soest, D. G. Fox and J. B. Russell. 1992. A net carbohydrate and protein system for evaluating cattle diets. II. Carbohydrate and protein availability. J. Anim. Sci. 70:3562-3577.

Statistix7. 2000. User's manual. Analytical Software, Tallahassee, FL, USA.

Ware, D. R., P. L. Read and E. T. Manfredi. 1988. Pooled summary of eight feedlot trials evaluating performance and carcass characteristics of steers fed Lactobacillus acidophilus strain BT138. J. Anim. Sci. 66(Suppl. 1):436. 